\title{
ORGANISATIONAL COMPETENCE
}

\section{VS TRANSFERABILITY OF KNOWLEDGE \\ IN CLUSTER ORGANISATIONS \\ AND TECHNOLOGY PARKS}

\author{
ANNA MARIA LIS* \\ JOLANTA ŽEMGULIENE்
}

\begin{abstract}
A B S TRACT
The main paper aims to evaluate the impact of organisational competence on knowledge and information flows within cluster organisations and technology parks, with particular emphasis on innovative content knowledge. The paper addresses the research question: "What set of competencies of cooperating companies allows access to information and knowledge in cluster and parks structures?" The authors report their findings from a quantitative study carried out in four cluster organisations and three technology parks functioning in Poland. The research sample covered a total of 269 enterprises: 132 cluster members and 137 park tenants. The primary method of data collection was a survey questionnaire. Data analysis was conducted using the interdependence of variables, ANOVA, and logistic regression. The research showed that the surveyed enterprises from both analysed groups preferred cooperation with partners of a similar level of competence development and the same or complementary scope of competence. This set of competencies of cooperating organisations also guaranteed better access to information and knowledge resources, including confidential information and new knowledge. This study additionally indicated that the knowledge creation activities performed by the cooperating cluster organisations depended on the proximity of the competencies of organisations as well as on the nature of the information, disseminated within the cluster organisations. The theoretical contribution is related to the results obtained by analysing the phenomenon of information and knowledge dissemination in cluster and park structures, revealing the impact made by the competence proximity of cooperating organisations on the access to this such resources. Thus, the findings supplement the state-of-the-art knowledge of the concept of industrial clusters by presenting a broader view on cooperation developed in geographical proximity, based on a set of various partner competencies.
\end{abstract}

KEY WORDS

cluster, cluster organisation, technology park, industrial park, competences, proximity, cooperation

$10.2478 /$ emj-2020-0013
Anna Maria Lis

Gdańsk University of Technology, Poland ORCID 0000-0002-1527-7796

*Corresponding author: e-mail: Anna.Lis@zie.pg.gda.pl

Jolanta Žemgulienè

Vilnius University, Lithuania ORCID 0000-0002-6085-4046

\section{INTRODUCTION}

In the context of the knowledge economy, business strategists associate regional clusters of affiliated companies and other institutions with a sustainable competitive advantage. Scholars highlight the benefits of the process of corporate cooperation or integration, both for the clustering companies and for the economic growth of the region (Ostergaard \& Park, 2015). In most studies, a core implication is that positive clustering effects result from knowledge or Marshallian externalities (Tallman et al., 2004; Ostergaard \& Park, 2015; Ter Wal \& Boschma, 2011). The literature

Lis, A. M., \& Žemgulienè, J. (2020). Organizational competence vs transferability of knowledge in cluster and park structures. Engineering Management in Production and Services, 12(2), 83-98. doi: 10.2478/emj-2020-0013 
explains the effect of knowledge exchange based on reference to extensive local networks, a common institutional environment, and the geographic proximity of firms. As firms are linked with the cluster network of knowledge exchange, clustering may impact the variety of knowledge resources and capabilities of an individual firm.

In addition to structural and geographical proximity factors, there are other preconditions for the dissemination of knowledge among companies in regional or technological clusters. Routines and processes of an organisation enable the transferability of information within cluster companies, their access to knowledge and the capacity to exploit it in the activities of new knowledge creation. Processes and routines of an organisation are the mechanism, by which the organisation responds to the external environment (information or knowledge). In a capability-based theoretical perspective, organisational competence is the resource that enables an organisation to function or respond to the signals of the environment (Nelson \& Winter, 2000; Teece et al., 1997). The scientific literature has given less attention to the impact made by the competence of organisations forming a cluster on the involvement of these companies in the knowledge creation activities, implemented following the principles of cooperation. However, in the practice of regional clusters in terms of the access to knowledge, innovative knowledge creation processes, and the factors influencing them are particularly important.

The research aims to empirically evaluate the impact of organisational competence on knowledge and information flows within clusters, as well as to evaluate how the dissemination of information about the cluster partners and cluster environment influences the transfer of innovative content knowledge within studied entities. In the study, a knowledge-based approach was applied to examining access to information and knowledge for cluster companies that fall into different categories of competencies.

The authors report the findings from their quantitative study based on an analysis of four cluster organisations and three technology parks operating in Poland. The research goes beyond the state-of-the-art knowledge in relation to the concept of industrial clusters, by exposing a broader view on cooperation developed in geographical proximity, based on a set of various partner competencies, especially since the authors included two types of organisations with cluster attributes. The choice of a cluster and park structures for the study was affected by the similarities observed between them. Cluster organisations, also named cluster initiatives (Sölvell et al., 2003; Lindqvist et al., 2013; Štverková \& Mynarzová, 2017; Lis, 2018, 2019), are understood as formally established organisations, functioning at a higher level of aggregation, composed of institutional members that consciously joined them (Lis, 2018). With regard to park structures, they are organisations that support the development of entities located in them, especially in the area of innovation and technology transfer. Both cluster organisations and technology parks are instruments of innovation policy to foster the growth of firms and regions via networking. Both concepts emphasise the significance of geographical proximity for the development of relationships and cooperation among entrepreneurs, who undertake their operations under conditions characteristic not only to a particular locality but also a particular industry. Geographical proximity is also considered a source of a privileged position taken by enterprises in their access to knowledge, its generation and distribution. Therefore, technology parks can be treated as a special kind of cluster structure, with great geographical proximity. However, despite the similarities between cluster and park structures, the additional cognitive value comes from the possibility of comparing both groups of entities. Cluster organisations and technology parks differ at the level of geographical proximity (in parks, this dimension of proximity is much more developed than in cluster organisations functioning under a greater location dispersion of their members), as well as competence proximity, both in the aspect of the scope of competences (technology parks, due to the greater sectoral range, characterised by a greater variety of competences of the cooperating partners) and at the level of competence development (in parks, due to the requirement of innovation, there are higher entry barriers than in cluster structures, which can result in a higher level of competence). A comparative study will help to identify the differences and similarities among cluster and park structures. Although the study was conducted in Poland, it offers findings that may be interesting for other states, especially for European countries, with a similar innovation policy (including cluster-based policy) to that of Poland.

The paper is organised as follows. The first section contains a literature review on the issues of transferability of information and knowledge and organisational competence in clusters. Based on the literature review, three propositions were formulated and then tested in the empirical part. The second section provides a methodology description, while the third reports the empirical results. Finally, discussion and conclusions are provided in the final sections. 


\section{LITERATURE REVIEW}

\subsection{ORGANISATIONAL COMPETENCE AND CLUSTER COMPETENCE}

Based on the analysis of organizational competence from the theoretical perspective of knowledge management, authors acknowledge different levels of competence depending on the scale of performance and outcomes. Individual competence is relevant to individual performance and tasks within an organisation, and the competence of the group or organisation is relevant to the achievement of operational tasks important to the whole organisation.

The ontological perspective of the concept of competence clearly links two elements - ability (to do work, to act, to accomplish something) and expression (competence manifests itself through performance as a direct perception or measurement of the competence is impossible) (Miranda et al., 2017). As Danneels (2016) have noted, competence has material as well as cognitive components.

Obviously, competence as a complex of knowledge, skills experience, motives, and traits is a characteristic of individuals. Individual competencies are material and cognitive abilities of individuals that enable them to perform the job-producing results consistent in terms of functional requirements and in line with organisational environment restrictions (Boyatzis, 1982).

Organisational competence is not the sum of individual competencies, but rather a dynamic set of correlating and complementary competencies that function within organisational structures and enable organisation's sustainability and competitive advantage. Organisational performance in a defined environment to maximise the value generated by organisational resources is an expression of organisational competence that, albeit with different interpretations, is recognised in the evolutionary theory and strategic management literature (Table 1).

As some approximation, organisational competence is considered as an organisation's asset that is referred to as the mechanism that supports the organisation's response to signals of the environment (Nelson \& Winter, 2000). In the capability-based theoretical perspective, the concept of competence is close to that of dynamic capabilities (Teece \& Pisano, 1994; Teece et al., 1997). In the resource-based view, an organisation is characterised as a bundle of organisation-specific resources (Wernerfelt, 1995). Capabilities and compe-

Tab. 1. Theoretical perspective of organisational competence

\begin{tabular}{|c|c|c|}
\hline THEORETICAL PERSPECTIVE & COMPETENCE CONTENT & REFERENCE \\
\hline $\begin{array}{l}\text { Evolutionary economics } \\
\text { (firm-level ontogenetic } \\
\text { evolution) }\end{array}$ & $\begin{array}{l}\text { The specific content of economic behaviour addresses the issue of basic be- } \\
\text { haviour continuity in terms of skills, routines, learning, cognition (elements } \\
\text { associated with competence). } \\
\text { Competence is built in evolution economics - organisations possess } \\
\text { bounded rationality due to the lack of competence. Competence puzzle } \\
\text { focuses on the role of learning and practice. } \\
\text { Organisational routine is treated as an organisational analogue of individual } \\
\text { skill. Routinised behaviour can be complex and effective }\end{array}$ & $\begin{array}{l}\text { Nelson and Winter } \\
(2002)\end{array}$ \\
\hline $\begin{array}{l}\text { Evolutionary economics } \\
\text { (dynamic capabilities) }\end{array}$ & $\begin{array}{l}\text { Dynamic capabilities as the source of competitive advantage. "Capabilities } \\
\text { emphasise the key role of strategic management in appropriately adapting, } \\
\text { integrating, and reconfiguring internal and external organisational skills, } \\
\text { resources, and functional competences toward changing environment" } \\
\text { (Teece and Pisano, 1994:1). } \\
\text { Organisational competences are defined as distinctive routines or processes } \\
\text { that are enabled by integrated clusters of firm-specific assets, individuals } \\
\text { and groups (Teece et al., 1997:516). } \\
\text { Firm's dynamic capabilities are determined by processes, positions and } \\
\text { paths }\end{array}$ & $\begin{array}{l}\text { Teece and Pisano } \\
\text { (1994), Teece et al. } \\
\text { (1997), Winter (2003), } \\
\text { Eisenhardt and Martin } \\
\text { (2000) }\end{array}$ \\
\hline $\begin{array}{l}\text { Strategic management } \\
\text { theory (the core compe- } \\
\text { tence approach) }\end{array}$ & $\begin{array}{l}\text { Define core competences as roots of competitiveness. } \\
\text { Provide a competence-based organisation's concept. } \\
\text { Identified methods for core-competence building }\end{array}$ & $\begin{array}{l}\text { Prahalad and Hamel } \\
\text { (1990) }\end{array}$ \\
\hline $\begin{array}{l}\text { Strategic management } \\
\text { theory (resource-based } \\
\text { view of the firm) }\end{array}$ & $\begin{array}{l}\text { Propose an idea to look at a firm as a set of resources rather than products. } \\
\text { Resources are defined as tangible and intangible assets, such as knowledge, } \\
\text { routines (effective procedures) that are difficult to replicate. } \\
\text { Capabilities and competences are identified as resources }\end{array}$ & $\begin{array}{l}\text { Wernerfelt (1984), } \\
\text { Wernerfelt (1995), } \\
\text { Amit and Schoemaker } \\
(1993)\end{array}$ \\
\hline
\end{tabular}


tencies are considered as resources that, under certain features of being valuable, rare, inimitable, non-substitutable, can be a source of competitive advantage for an organisation (Kogut \& Kulatilaka, 2001; Santos $\&$ Eisenhardt, 2005). On the level of a firm, the competence theory recognises competence as the antecedent of an economic agent's ability to solve problems. Competence implications to inter-firm diversity assumption were stated in evolutionary-type research. In line with the arguments of the evolutionist theory concerning the factors and mode of decision-making behaviour, Dosi \& Marengo stated, that "competences represent the problem-solving features of particular sets of organizational interactions, norms and explicit strategies" (Dosi \& Marengo, 2000, p. 53). If decisionmaking episodes are considered to be a challenge for individuals, groups or organisations in terms of problem-solving ability, this definition of competence reveals that organisational forms (i.e., particular sets of organisational interactions, norms, strategies) have an influence on decision-making, and competence affects the behaviour of economic agents. Based on this theoretical perspective, economic agents use their competence to compete for best (i.e., optimal) decisions. Competence is defined as a specific asset of a firm that is supported by the use of organisational knowledge relevant to determine performance outcomes that maximise the opportunity value of the resources portfolio of the organisation. However, organisations perform as systems with interconnected actions of individual decision-makers, and this raises some problems of causal ambiguity about the courses of organisational outcomes and inefficiency in terms of possibility to find some optimal solution (Cohen, 1987). Dosi and Marengo considered cognitive and political arguments regarding the basis of an organisation's common knowledge and hierarchical relations inside the organisation that relate diversity of preferences of individual decision-makers with the possibility to enhance various organisational knowledge and its adaptability (Dosi \& Marengo, 2000, p. 59). Organisational architecture and routines of a performance organisation enable the firm to generate an efficient outcome in the use of endowments. The perspective of knowledge-based organisational competence primarily focused on a few epistemological assumptions. First, competence is represented by the decision-making power of members in the organisation, which depends on the information processing capabilities and learning; second, in theory, the aim of problemsolving entails the optimum action response of the organisation to environmental signals. The decisionmaking context involves the relationship between an organisation and the environment, in which it operates, and also internal rules that govern the behaviour of the organisation. Third, as a decision agent do not possess perfect decision procedures appropriate for a rational solution, and perfect information is not available, problem-solving solutions are the outcomes of emergent computation and interpretation. The problem-solving knowledge or competence in empirical grounds is related to the procedures or routines that are learned via experience and adaptation gained during actual problem-solving activity.

Some authors attribute the competence consideration to the meso-level unit of analysis - the regional competence (Niosi \& Bas, 2005, p. 32). Industrial regions, as well as organisations, exploit endowments and possess some core competences that create a competitive advantage for regions. Regional competences comprise competences of individual organisations located in the regional proximity. As far as a regional competence is based on common knowledge that allows different organisations to coevolve, one particular competence - the capacity to cooperate - is considered the contingent upon the interaction within the multiagent setting. Different firms participating in the regional cluster have different aims and divergent systems of preferences; however, the cooperation is available on the basis of some harmonised aims (Lis, 2018, 2019). Problem solving actions within a group of interrelated organisations is based on the set of competences available to individual firms. Action modelling within a group of interrelated economic agents requires even more coordination and communication efforts as compared to the multiagent setting of an individual organisation. Regional competence as the knowledge gained from experience and learning includes not only knowledge shared by companies participating in regional cooperation but also inter-organisational communication structures that allow forming and disseminating common rules and routines. The development of common rules support relationships built inside the group of organisations and knowledge spillovers. As Heraud (1997) suggested, the interaction between companies located in regional proximity influences knowledge-creation and performance. Niosi and Bas (2001) presented some evidence of knowledge spillovers in biotechnology clusters in Canada. The authors stated that knowledge spillovers depended on the amount of knowledge produced by private companies and public institutions. The geographical proximity encourages processes of cooperation, collective learning, informal and tacit knowledge transfers. Firms operating in a particular socio-geographical entity form integrated supply chains, clusters 
of subcontractors, also share certain local labour resources and knowledge infrastructure of public and private research institutions. This tends to form the endogenous basis for knowledge diffuse via communication. The common base of knowledge across the firms of a regional cluster and local social endowments indicate the cumulative nature of cluster competence.

Competence at the individual, organisational or cluster level refers to the stock of knowledge accumulated by individuals or used by groups of individuals in activities of an organisation. Organisational competence confers the absorptive capacity of a firm. According to Cohen and Levinthal (1990), absorptive capacity is the ability to acquire, communicate or transmit information across units and to individuals of an organisation and the ability to assimilate and exploit external knowledge in organisational learning and performance.

\subsection{TRANSFERABILITY OF INFORMATION IN THE CLUSTER AND DIFFERENTIATED COMPE- TENCES}

Organisations involved in the cluster are in constant communication with the partner organisations as well as other actors in the external environment. The capability of an organisation to integrate externally originated information into knowledge-creation activities depends on the type of information acquired, as well as the organization's technological capability and absorptive capacity (Lis \& Rozkwitalska, 2020). Different authors provided different approaches to the absorption capacity concept (Cohen \& Levinthal, 1990; Camison \& Fores, 2010; Lane \& Lubatkin, 1998). The absorption model proposed by Cohen and Levinthal involves the absorption and integration of knowledge that is valuable and available in the organisational environment. The relative absorptive capacity model, introduced by Lane and Lubatkin, considers the mechanism of knowledge transfer (Camison \& Fores, 2010; Lane \& Lubatkin, 1998). Knowledge resides in the mind of an individual and acquires meaning in the context of an organisation. When an organisation accepts knowledge, the sender-recipient connection operates, with one organisation as the sender and the other as the recipient. The organisation's capability to acquire, assimilate and apply knowledge, and the ability of an organisation to integrate external knowledge depend on the compatibility of knowledge processing and application systems operating in organisations of the knowledge provider and recipient (Lane \& Lubatkin, 1998; Swiadek, 2015). It is considered that knowledge absorption is not only about the processes and routines of knowledge acquisition and transfer within an organisation, but also about the organisation's compatibility of knowledge systems or competence. While firms hold internally developed systems and routines designed to facilitate the acceptance of externally originated knowledge, such systems are relatively coherent and contextual, and reflect exogenous or institutional clauses. Firms participating in the cluster share conditions and institutional power (the environment), such as business regulatory regime, employment regulations, legal requirements that have an impact on business transactions; as a result, there is an increasing compatibility between absorption capacities and knowledge transfer capabilities within companies operating in a territorial cluster (Tallman et al., 2004).

Proposition 1: The dissemination of knowledge within cluster firms depends on the proximity of organisation's competence.

The capability to assimilate new knowledge depends on the learning ability of an organisation. Innovative organisations acquire specific knowledge resources and skills that are related to the arrangement of recognition and cognition of incoming information. Diffusion of new knowledge within clusters of innovative organisations is likely to be more effective than the dissemination of information across geographically related clusters of organisations.

Proposition 2: The dissemination of knowledge within cluster firms depends on specific features of the organisations, such as being an innovative high-tech industrial company.

Internal processes of knowledge integration and learning depend on the nature of the incoming information. General information about a cluster partner organisation usually does not contain complex and sophisticated technological knowledge. Receiving and transmitting this information does not require specialised capabilities or expertise of those individuals to whom the information is provided. An effective management of general externally originated information requires background knowledge of shared language and symbols, knowledge of internal communication system, and also an inter-organisational relationship mechanism. Significant and confidential information provided to a cluster partner organisation usually includes substantive knowledge of a competitor's product or innovative performance. Effective communication, assimilation and exploitation of such information require complementary expertise within the recipient organisation. The capacity to absorb specialised information can be facilitated by the capability to manage flows of general information, e. g. as described by 
Cohen and Levinthal, the "knowledge of who knows what, who can help with what problem or who can exploit new information" (Cohen \& Levinthal, 1990, p. 133). Also, the capacity to absorb confidential information can be enhanced by a close relationship with a cluster partner. The capacity to absorb information containing technical knowledge of product or process innovation could be enabled by individuals possessing particular expertise sufficient for the communication with external sources of knowledge. The ability to integrate such information into the organisation's activity and the capacity to assimilate and utilise it depends on the competence diversity across individuals communicating knowledge-based information. The overlap of knowledge or competence among individuals receiving and transmitting technical information is required for effective communication.

Proposition 3: The access to general and selected information about cluster partners is related to the dissemination of new knowledge within the cluster companies.

\section{RESEARCH METHODS}

The article reports the outcomes of the quantitative study, which is a section of larger research concentrating on the analysis regarding the level of development of cooperative relationships in localised cooperation networks on the example of cluster and park structures. The current study aims to answer the following research question: What set of competencies of cooperating companies allows access to information and knowledge in cluster organisations and technology parks? As for the theoretical basis of the research, the authors predict that the competence proximity has an impact on the access to knowledge in cluster and park structures (Propositions 1 and 3 ) and this access is better for companies with high competences (Proposition 2). In this study, the competence proximity is understood as a similarity of structured and dynamic competence systems, both in terms of the scope of competence (CPs) and the level of competence development (CPl) (Lis, 2018, 2019).

The research was carried out in two groups of entities: cluster and park structures functioning in Poland. The study of cluster organisations was conducted in 2017, in four purposefully selected cluster organisations operating in Poland: in two cluster organisations representing the ICT industry (the Mazovia Cluster ICT [MC ICT] and the Interizon: the Pomeranian Region ICT Cluster) and two from the metal industry (the Metal Cluster of the Lubuskie Province [MCLP] and the Metal Working Eastern Cluster [MWEC]). The research sample consisted of 132 cluster enterprises: 51 from metal cluster organisations (38 from MWEC and 13 from MCLP) and 81 from ICT cluster organisations (45 from MC ICT and 36 from the Interizon). In the second group, the study was conducted in 2019, in three parks: the Pomeranian Science and Technology Park Gdynia [PSTPG], the Gdańsk Science and Technology Park [GSTP] and the Bydgoszcz Industrial and Technological Park [BITP]. The research covered 137 park tenants: 81 in PSTPG, 39 in GSTP and 17 in BITP.

The primary method of data collection was a survey questionnaire. The interviewees were the owners, top managers or specialists of the companies who had the most comprehensive and accurate knowledge about the realities of their company functioning in cluster organisations or technology parks. The questionnaire referred to the following topics: 1) the competence proximity in terms of the scope of competences [CPs]; 2) the competence proximity in terms of the level of competence development [CPI]; 3) the access to information and knowledge [AIK] (Table 2). With regard to the competence proximity in terms of the scope of competences [CPs], the study focused on three cases: the cooperation based on the same (or very similar) [CPs1], different but complementary [CPs2] and a very different [CPs3] set of partner competences. The competence proximity in terms of the level of the competence development $[\mathrm{CPl}]$ was assessed in relation to the level of competence of other companies. In turn, access to information and knowledge [AIK] included various types of resources, ranging from general [AIK1] and detailed [AIK2] information, through priority in obtaining relevant information about the environment [AIK3], to confidential information [AIK4] and knowledge [AIK5]. Data analysis was conducted using the interdependence of variables (with using Kendall's tau-b coefficient, Cramer's V), ANOVA, and logistic regression.

\section{RESULTS}

\subsection{COMPETENCE PROXIMITY}

The research conducted in the group of cluster organisations shows that if cluster enterprises decided to cooperate with other cluster members, they chose mainly those enterprises that had the same or very similar scope of competence [CPs1], which means that they operated in the same industries and represented a similar business profile. Cooperation with enterprises 
Tab. 2. Variables in the study

\begin{tabular}{|c|c|}
\hline \multicolumn{2}{|c|}{ COMPETENCE PROXIMITY IN TERMS OF THE SCOPE OF COMPETENCES [CPS] } \\
\hline CPs1 & $\begin{array}{l}\text { Our company works with cluster companies/park tenants that have the same or very similar competence (belong to the } \\
\text { same industry, have a similar business profile) }\end{array}$ \\
\hline CPs2 & $\begin{array}{l}\text { Our company works with cluster companies/park tenants that have expertise in a different field to ours (they belong to } \\
\text { the same industry, and their competencies are complementary to ours) }\end{array}$ \\
\hline CPs3 & $\begin{array}{l}\text { Our company works with cluster companies/park tenants that have completely different competences (they belong to } \\
\text { other industries) }\end{array}$ \\
\hline \multicolumn{2}{|r|}{ Likert scale (1-5): Definitely not (1) Rather not (2) Hard to say (3) Rather yes (4) Definitely yes (5) } \\
\hline \multicolumn{2}{|c|}{ COMPETENCE PROXIMITY IN TERMS OF THE LEVEL OF COMPETENCE DEVELOPMENT [CPL] } \\
\hline \multicolumn{2}{|c|}{$\begin{array}{l}\text { In the cluster/park, we cooperate primarily with companies whose level of development (te } \\
\text { 1. Much lower than the level represented by our company } \\
\text { 2. Lower than the level represented by our company } \\
\text { 3. Similar to the level represented by our company } \\
\text { 4. Higher than the level represented by our company } \\
\text { 5. Much higher than the level represented by our company } \\
\text { 6. None of the above because we do not cooperate with cluster companies/park tenants }\end{array}$} \\
\hline \multicolumn{2}{|c|}{ ACCESS TO INFORMATION AND KNOWLEDGE [AIK] } \\
\hline AlK1 & $\begin{array}{l}\text { One of the effects of joining the cluster/location in the park is that my company has gained access to a wide variety of } \\
\text { information (albeit general information) }\end{array}$ \\
\hline AIK2 & $\begin{array}{l}\text { One of the effects of joining the cluster/location in the park is that my company has gained access to selected informa- } \\
\text { tion, fully tailored to the profile and needs of my business }\end{array}$ \\
\hline AIK3 & $\begin{array}{l}\text { One of the effects of joining the cluster/location in the park is that my company has gained priority in receiving impor- } \\
\text { tant information about changes in the external environment }\end{array}$ \\
\hline AIK4 & $\begin{array}{l}\text { One of the effects of joining the cluster/location in the park is that my company is less worried about sharing certain } \\
\text { confidential information with selected cluster companies }\end{array}$ \\
\hline AlK5 & $\begin{array}{l}\text { One of the effects of joining the cluster/location in the park is that my company, together with other selected cluster } \\
\text { companies/park tenants, takes part in processes of creating new knowledge (through working groups, project groups } \\
\text { etc.) }\end{array}$ \\
\hline
\end{tabular}

from the same industry, but with complementary competences was slightly less frequently established [CPs2]. In turn, the least popular in the surveyed cluster organisations was the cooperation of enterprises with a completely different scope of competences and belonging to other sectors industries [CPs3] (Table 3). In the three discussed cases - the cooperation of enterprises with the same (or very similar), different (but complementary) and completely different scope of competences - the average was increasingly lower: from 2.8 points to 2.6 points up to 2.3 points. The above analysis completes the dominant value. To the question about the cooperation based on the same or very similar scope of competences, the most frequently chosen answer was No 4 (moderately positive), while to the questions about both a different and completely different set of competences, it was the answer No 1 (definitely negative).

The study shows that about $40 \%$ of cluster enterprises gave a moderate or definitely positive answer to the question about cooperation with enterprises with the same (or very similar) scope of competences, while a different or completely different scope of competences was the basis for cooperation for, respectively, approx. $30 \%$ and approx. $17 \%$ of respondents. It should be noted, however, that in all three cases moderate or extremely negative votes prevailed (i.e., more than $42 \%$ of respondents did not cooperate with cluster enterprises with the same or similar scope of competences, almost 50\% did not cooperate with enterprises with a different yet complementary scope of competences, while the majority, over $61 \%$, did not develop crosssectoral cooperation based on a completely different scope of competences). This may indicate that a large group of cluster enterprises has not entered into any cooperation within the cluster organisation, regardless of competencies of the partners.

Regarding competence proximity in terms of the level of competence development [CPl], the study shows that enterprises in the analysed cluster organisations cooperated primarily with enterprises with a similar (to the level presented by their own organisation) level of competence development - the answer (No 3) was given by almost half of the respondents. 
Tab. 3. Competence proximity [CPs] in terms of the scope of competences in cluster organisations and technology parks $(\mathrm{N}=132,137)$

\begin{tabular}{|c|c|c|c|c|c|c|c|c|c|c|c|c|}
\hline \multirow{2}{*}{ VARIABLES } & \multicolumn{6}{|c|}{ CLUSTER ORGANISATIONS } & \multicolumn{6}{|c|}{ TECHNOLOGY PARKS } \\
\hline & MIN & MAX & MEAN & StD. DEV. & MEDIAN & MODE & MiN & MAX & MEAN & StD. DEV. & MEDIAN & MODE \\
\hline CPs1 & 1 & 5 & 2.80 & 1.36 & 3 & 4 & 1 & 5 & 2.78 & 1.21 & 3 & 2 \\
\hline CPs2 & 1 & 5 & 2.60 & 1.24 & 3 & 1 & 1 & 5 & 2.85 & 1.21 & 3 & 2 \\
\hline CPs3 & 1 & 5 & 2.27 & 1.16 & 2 & 1 & 1 & 5 & 2.93 & 1.28 & 3 & 3 \\
\hline CPI & 1 & 6 & 3.88 & 1.42 & 3 & 3 & 1 & 6 & 3.26 & 0.83 & 3 & 3 \\
\hline
\end{tabular}

This is also confirmed by the mean value (3.9). For over $15 \%$ of enterprises, participation in the cluster organisation was an opportunity to establish cooperation with enterprises with a higher level of competence development. A relatively high percentage of respondents admitted that they did not cooperate with other cluster enterprises at all (over 27\%) (hence, they were unable to answer the question regarding the level of competence development of their cluster partners).

The cooperation in the surveyed parks was slightly different than in cluster organisations considering the scope of tenant competence. The differences in the answers in the three analysed categories [CPs1-CPs3] were not as pronounced as in the case of cluster organisations. The mean value was between 2.8 and 2.9 (Table 3). Positive answers were at a level slightly above $30 \%$, while negative concerned more than $40 \%$ of respondents in each of the three categories. In turn, a relatively large (compared to the results obtained for cluster organisations) part of the respondents (16\%) indicated an extremely positive response regarding the cooperation with enterprises with completely a different scope of competences.

Comparing the answers regarding the level of competence development obtained in the group of technology parks and cluster organisations, a slightly lower result was obtained (the mean at the level of 3.3). About $60 \%$ of respondents representing the surveyed parks admitted that they cooperated with enterprises with a similar level of competence development. In turn, in the case of over $28 \%$ of respondents, their cooperation partners were companies with higher or much higher competences. Extremely low (less than 1\%) was the share of enterprises that admitted not cooperating with other park tenants at all.

\subsection{ACCESS TO INFORMATION AND KNOWLEDGE}

The analysis included access to information and knowledge $[\mathrm{AIK}]$ of entities grouped in cluster organi- sations and technology parks, which is closely related to the development of competence proximity in terms of the level of competence development. In the group of cluster entities, the most noteworthy is the relatively high percentage of respondents who are unable to give an unambiguous answer. To four questions (AIK2AIK5), the answer "hard to say" was the most frequent (reaching the percentage of indications at the level from about $30 \%$ to $41 \%$ ). The question about wide access to various general information in the cluster organisation [AIK1] had the smallest share of undecided respondents (about 1/4). This area also received the highest evaluation by the surveyed enterprises (the average value, in this case, was 3.5 points) with the highest share of satisfied votes (the total of almost $60 \%$ ) (Table 4). Results similar in terms of the mean value (approx. 3) were obtained for questions regarding the access to selected information enabling better identification of sources of missing resources [AIK2] and significant information about the environment, key from the point of view of business activity [AIK3]. Although in both areas, total positive votes outweighed the negative, differences were small. Slightly more positive votes (almost 37\%) were cast for AIK3, considering both moderate and extreme answers, while AIK2 had about $34 \%$ of positive answers. The lowest mean values were achieved for last two categories: sharing confidential information reserved only for trusted partners [AIK4] (2.8) and participating in the process of creating new knowledge [AIK5] (2.95). In both cases, negative votes dominated, constituting approximately $36 \%$ and $37 \%$ of the given answers.

The study shows that park tenants located in the studied parks have the best access to general information [AIK1] (the mean value: $3.3,47 \%$ of positive answers) and the worst to confidential information, which is reserved for trusted partners [AIK4] (the mean value: $2.5,55 \%$ of negative answers). The means obtained for the other three variables were similar and ranged from 2.7 [AIK3\&AIK 5] to 2.9 [AIK 2] (Table 4). In surveyed parks, as in cluster organisations, 
Tab. 4. Access to information and knowledge $[\mathrm{AIK}]$ in cluster organisations and technology parks $(\mathrm{N}=132,137)$

\begin{tabular}{|c|c|c|c|c|c|c|c|c|c|c|c|c|}
\hline \multirow{2}{*}{ VARIABLES } & \multicolumn{6}{|c|}{ CLUSTER ORGANISATIONS } & \multicolumn{6}{|c|}{ TECHNOLOGY PARKS } \\
\hline & MiN & MAX & MEAN & STD. DEV. & MEDIAN & MODE & Min & MAX & MEAN & STD. DEV. & MEDIAN & MODE \\
\hline AIK1 & 1 & 5 & 3.52 & 1.11 & 4 & 4 & 1 & 5 & 3.26 & 1.00 & 3 & 4 \\
\hline AIK2 & 1 & 5 & 3.09 & 1.10 & 3 & 3 & 1 & 5 & 2.89 & 0.90 & 3 & 3 \\
\hline AIK3 & 1 & 5 & 3.02 & 1.06 & 3 & 3 & 1 & 5 & 2.74 & 0.94 & 3 & 2 \\
\hline AIK4 & 1 & 5 & 2.76 & 1.04 & 3 & 3 & 1 & 5 & 2.49 & 1.10 & 2 & 2 \\
\hline AIK5 & 1 & 5 & 2.95 & 1.20 & 3 & 3 & 1 & 5 & 2.74 & 1.18 & 3 & 3 \\
\hline
\end{tabular}

a large share of respondents could not provide an unequivocal answer on the access to information and knowledge in the park (it ranged from approx. 24\% to over $47 \%)$.

\subsection{RELATIONSHIP BETWEEN THE COMPE- TENCE PROXIMITY AND ACCESS TO INFORMA- TION AND KNOWLEDGE}

In the case of competence proximity in terms of the scope of competences, the cause-and-effect relationship can be logically assumed, i.e., it is the cooperation of entities with a given set of competences that affects access to a specific pool of information and knowledge.

The study conducted in cluster organisations shows that there were statistically significant, positive relationships between all components of the CPs and AIK constructs (Table 5). On this basis, it can be concluded that the cooperation with other cluster partners, regardless of their scope of competence, remains in a positive relationship with the access to additional pool of information (including general, selected, significant and confidential information) and knowledge.

The observed differences in the value of the correlation coefficient are small. It turned out that the more diverse the competences of the cooperating cluster entities, the weaker the correlation. The strongest positive relationships were noticed when cluster enterprises cooperated with companies with very similar scope of competences [CPs1]. The highest values of the correlation coefficient were noted for access to selected information enabling the identification of sources of missing resources [AIK2] $(0.416, p \leq 0.001)$, confidential information [AIK4] $(0.405, \mathrm{p} \leq 0.001)$, and new knowledge [AIK5] $(0.359, \mathrm{p} \leq 0.001)$. Based on the obtained results, it can therefore be concluded that cluster cooperation facilitated the access to information and knowledge for associated members. The scope of competence of the partners seems to be secondary, only to a small extent determining access to the analysed pool of resources. However, with the increase in the competence distance of partners, this access could become more and more difficult.

Slightly different results were obtained in the group of park tenants. Here, access to information and knowledge $[\mathrm{AIK}]$ is more determined by the scope of competences of the partners [CPs]. Entities that cooperated with enterprises with the same (or very similar) [CPs1] as well as different (but complementary) [CPs2] scope of competence had better access to the analysed resources (Table 5). In the case of cooperation based on the same or very similar set of competences [CPs1], the entities involved in this cooperation received access to all types of distinguished resources ([AIK1]-[AIK5]). Interestingly, the value of the correlation coefficient is the lowest in the case of the most easily available general information [AIK1] (0.157), and one of the highest in the case of the most difficult resource - new knowledge [AIK5] (0.408). In the case of cooperation based on a different but complementary set of competencies [CPs2], correlations occurred with almost all compo-

Tab. 5. The results of the correlation analysis in cluster organisations and technology parks: [CPs] - [AIK] $(\mathrm{N}=132,137)$

\begin{tabular}{|c|c|c|c|c|c|c|c|c|c|c|c|}
\hline \multirow{2}{*}{ CPs } & \multirow{2}{*}{$\mathrm{CC} / \mathrm{P}$} & \multicolumn{5}{|c|}{ CLUSTER ORGANISATIONS } & \multicolumn{5}{|c|}{ TECHNOLOGY PARKS } \\
\hline & & AIK1 & AIK2 & AIK3 & AIK4 & AIK5 & AIK1 & AIK2 & AIK3 & AIK4 & AIK5 \\
\hline \multirow{2}{*}{ CPs1 } & Cc & $0.323^{* *}$ & $0.416^{* *}$ & $0.333^{* *}$ & $0.405^{* *}$ & $0.359^{* *}$ & $0.157^{*}$ & $0.415^{* *}$ & $0.211^{* *}$ & $0.258^{* *}$ & $0.408^{* *}$ \\
\hline & $p$ & 0.000 & 0.000 & 0.000 & 0.000 & 0.000 & 0.028 & 0.000 & 0.003 & 0.000 & 0.000 \\
\hline \multirow{2}{*}{ CPs2 } & Cc & $0.269^{* *}$ & $0.328^{* *}$ & $0.244^{* *}$ & $0.264^{* *}$ & $0.222^{* *}$ & 0.133 & $0.306^{* *}$ & $0.273^{* *}$ & $0.376^{* *}$ & $0.375^{* *}$ \\
\hline & $p$ & 0.000 & 0.000 & 0.001 & 0.000 & 0.002 & 0.061 & 0.000 & 0.000 & 0.000 & 0.000 \\
\hline \multirow{2}{*}{ CPs3 } & Cc & $0.194^{* *}$ & $0.277^{* *}$ & $0.305^{* *}$ & $0.170^{*}$ & $0.153^{*}$ & $0.208^{* *}$ & 0.084 & 0.124 & 0.073 & -0.048 \\
\hline & $p$ & 0.008 & 0.000 & 0.000 & 0.020 & 0.034 & 0.003 & 0.242 & 0.082 & 0.299 & 0.492 \\
\hline
\end{tabular}


nents of the AIK construct, except for general information [AIK1]. Also, in this case, the value of the correlation coefficient for new knowledge [AIK5] was very high (0.375), similar to access to confidential information [AIK4] (0.376). Research shows that the cooperation of entities with completely different competences [CPs3] does not determine access to most of the analysed types of information and knowledge. The only relationship that emerged in this case was access to general information [AIK1] (0.208).

The differences in access to knowledge and information in groups with various sets of competences were additionally evaluated by performing the analysis of variance of data covering both cluster companies and park tenants. The results of the variance analysis showed that access to both general and specific information as well as involvement in knowledge dissemination activities differed significantly between various groups of collaborating companies (Table 6).

Compared to the dissemination of information and knowledge within the group of different competence, in cooperation with companies with a similar field of expertise, partners gain more access to a variety of information, as well as are more willing to participate in knowledge dissemination processes.

The mean value of information and knowledge availability to cluster companies is interpreted by a measurement scale of the variable $(1-$ definitely no, 5 - definitely yes). Information availability and knowledge dissemination opportunities are more negatively evaluated by cooperating companies with different competencies, the mean value for all variables is barely 3 ; and among companies with similar or identi- cal competences, the mean for all variables of information and knowledge dissemination is statistically significantly higher, and for most variables reaches a rank value consistent with a positive rating. In all enterprise groups, the mean value is lower for variables of more complex information or knowledge dissemination.

In the case of competence proximity in terms of the level of competence development, it is difficult to logically determine the sides of a causal relationship. The correlation analysis conducted between competence proximity in terms of the level of competence development $[\mathrm{CPl}]$ and access to information and knowledge $[\mathrm{AIK}]$ in the surveyed cluster organisations shows a statistically significant relationship between the mentioned variables. The differences are very small - the highest value of the correlation coefficient was in the case of access to general information [AIK1] (0.324), and the lowest in the case of access to confidential information [AIK3] (0.274) (Table 7). Therefore, it can be concluded that there is a moderate relationship between the level of competence development $[\mathrm{CPl}]$ of cluster enterprises and the access to all distinguished information and knowledge resources [AIK] in cluster organisations.

In the case of surveyed parks, a statistically significant relationship between the analysed variables [CPl] and $[\mathrm{AIK}]$ occurred in relation to access to selected information [AIK2] (0.299) and the priority in access to significant information on the environment [AIK3] $(0.277)$ as well as access to general information [AIK1] (0.259). However, there was no correlation with regard to access to these most difficult resources, namely,

Tab. 6. Results of the analysis of variance in cluster organisations and technology parks: [CPs] - [AIK] (N=269)

\begin{tabular}{|c|c|c|c|c|c|c|c|c|}
\hline \multirow{3}{*}{ AIK } & \multicolumn{8}{|c|}{ COMPETENCE OF COLLABORATING ORGANISATIONS } \\
\hline & \multicolumn{2}{|c|}{$\begin{array}{c}\text { CPs1(1-2), (N=118) } \\
\text { (1) }\end{array}$} & \multicolumn{2}{|c|}{$\begin{array}{c}\text { CPs1(3), (N=53) } \\
\text { (2) }\end{array}$} & \multicolumn{2}{|c|}{$\begin{array}{c}\text { CPs1(4-5), (N=98) } \\
\text { (3) }\end{array}$} & \multicolumn{2}{|c|}{ TOTAL (N=269) } \\
\hline & MEAN & $\begin{array}{c}\text { StD. } \\
\text { DEVIATION }\end{array}$ & MEAN & $\begin{array}{c}\text { StD. } \\
\text { DEVIATION }\end{array}$ & MEAN & $\begin{array}{c}\text { StD. } \\
\text { DEVIATION }\end{array}$ & MEAN & $\begin{array}{c}\text { StD. } \\
\text { DEVIATION }\end{array}$ \\
\hline AIK1 & 3.02 & 1.18 & 3.51 & 0.99 & 3.76 & 0.77 & 3.38 & 1.06 \\
\hline
\end{tabular}

Parameters of ANOVA for variables (AIK1), (CPs1) $F=14.82, p=0.000<0.01$. The mean difference for the competence groups 1 and 2; 1 and 3 is significant at the 0.01 level

\begin{tabular}{|l|r|r|r|r|r|r|r|r|}
\hline AIK2 & 2.47 & 0.99 & 3.28 & 0.72 & 3.46 & 0.85 & 2.99 & 1.01 \\
\hline
\end{tabular}

Parameters of ANOVA for variables (AIK2), (CPs1) F=36.63, $p=0.000<0.01$. The mean difference for the competence groups 1 and 2; 1 and 3 is significant at the 0.01 level

\begin{tabular}{|l|r|r|r|r|r|r|r|r|}
\hline AIK3 & 2.49 & 1.00 & 3.21 & 0.93 & 3.16 & 0.90 & 2.88 & 1.01 \\
\hline
\end{tabular}

Parameters of ANOVA for variables (AIK3), (CPs1) F=17.35, $p=0.000<0.01$. The mean difference for the competence groups 1 and 2; 1 and 3 is significant at the 0.01 level

\begin{tabular}{|l|r|r|r|r|r|r|r|r|}
\hline AIK4 & 2.19 & 0.97 & 3.00 & 1.04 & 2.95 & 1.04 & 2.62 & 1.08 \\
\hline
\end{tabular}

Parameters of ANOVA for variables (AIK4), (CPs1) $\mathrm{F}=19.73, \mathrm{p}=0.000<0.01$. The mean difference for the competence groups 1 and 2; 1 and 3 is significant at the 0.01 level

\begin{tabular}{|l|r|r|r|r|r|r|r|r|}
\hline AlK5 & 2.29 & 1.09 & 3.13 & 1.00 & 3.36 & 1.13 & 2.84 & 1.20 \\
\hline
\end{tabular}

Parameters of ANOVA for variables (AIK5), (CPs1) $\mathrm{F}=28.12, \mathrm{p}=0.000<0.01$. The mean difference for the competence groups 1 and 2; 1 and 3 is significant at the 0.01 level 
Tab. 7. The results of the correlation analysis in cluster organisations and technology parks: [CPI] - $[\mathrm{AIK}](\mathrm{N}=132,137)$

\begin{tabular}{|c|r|r|r|r|}
\hline \multirow{2}{*}{$\begin{array}{c}\text { Access to information and knowledge } \\
\text { [AIK] }\end{array}$} & \multicolumn{2}{|c|}{ Cluster organisations } & \multicolumn{2}{|c|}{ Technology parks } \\
\cline { 2 - 5 } & Cramer's V & $\boldsymbol{p}$ & Cramer's V & 0.259 \\
\hline AIK1 & 0.324 & $p<0.0001$ & 0.299 & 0.000 \\
\hline AIK2 & 0.303 & 0.001 & 0.277 & 0.003 \\
\hline AIK3 & 0.322 & $p<0.0001$ & 0.240 & 0.048 \\
\hline AIK4 & 0.274 & 0.008 & 0.214 & 0.197 \\
\hline AIK5 & 0.301 & 0.001 & & 0.212 \\
\hline
\end{tabular}

Tab. 8. Results of the analysis of variance in cluster organisations and technology parks: [CPI] - $[\mathrm{AIK}](\mathrm{N}=230)$

\begin{tabular}{|c|c|c|c|c|c|c|c|c|}
\hline \multirow{3}{*}{ AIK } & \multicolumn{8}{|c|}{ COMPETENCE PROXIMITY OF COLLABORATING ENTERPRISES IN TERMS OF THE LEVEL OF DEVELOPMENT } \\
\hline & \multicolumn{2}{|c|}{$\begin{array}{l}\mathrm{CPL}(1-2)(\mathrm{N}=26) \\
\text { (1) }\end{array}$} & \multicolumn{2}{|c|}{$\begin{array}{l}\mathrm{CPL}(3)(\mathrm{N}=145) \\
(2)\end{array}$} & \multicolumn{2}{|c|}{$\begin{array}{l}\mathrm{CPI}(4-5)(\mathrm{N}=59) \\
(3)\end{array}$} & \multicolumn{2}{|c|}{ TOTAL $(\mathrm{N}=230)$} \\
\hline & Mean & $\begin{array}{c}\text { STD. } \\
\text { DEVIATION }\end{array}$ & MEAN & $\begin{array}{c}\text { STD. } \\
\text { DEVIATION }\end{array}$ & MEAN & $\begin{array}{c}\text { STD. } \\
\text { DEVIATION }\end{array}$ & MEAN & $\begin{array}{c}\text { STD. } \\
\text { DEVIATION }\end{array}$ \\
\hline AIK1 & 2.88 & 1.40 & 3.57 & 0.92 & 3.32 & 1.06 & 3.43 & 1.04 \\
\hline \multicolumn{9}{|c|}{$\begin{array}{l}\text { Parameters of ANOVA for variables (AIK1), (CPI) F=5.49, } \mathrm{p}=0.005<0.01 \text {. The mean difference for the competence groups } 1 \text { and } 2 \text { is } \\
\text { significant at the } 0.01 \text { level }\end{array}$} \\
\hline AIK2 & 2.46 & 1.17 & 3.28 & 0.92 & 2.85 & 0.91 & 3.07 & 0.99 \\
\hline \multicolumn{9}{|c|}{$\begin{array}{l}\text { Parameters of ANOVA for variables (AIK2), (CPI) F=10.35, } \mathrm{p}=0.000<0.01 \text {. The mean difference for the competence groups } 1 \text { and } 2 ; 2 \\
\text { and } 3 \text { is significant at the } 0.01 \text { level }\end{array}$} \\
\hline AIK3 & 2.50 & 1.17 & 2.99 & 0.90 & 3.02 & 1.11 & 2.94 & 1.00 \\
\hline \multicolumn{9}{|c|}{$\begin{array}{l}\text { Parameters of ANOVA for variables (AIK3), (CPI) F=2.97, } \mathrm{p}=0.054>0.05 \text {. Mean differences for competence groups are not statistically } \\
\text { significant }\end{array}$} \\
\hline AlK4 & 2.23 & 1.37 & 2.71 & 1.04 & 2.76 & 1.09 & 2.67 & 1.10 \\
\hline \multicolumn{9}{|c|}{$\begin{array}{l}\text { Parameters of ANOVA for variables (AIK4), (CPI) } F=2.39, p=0.094>0.05 \text {. Mean differences for competence groups are not statistically } \\
\text { significant }\end{array}$} \\
\hline AlK5 & 2.42 & 1.42 & 3.05 & 1.15 & 2.80 & 1.21 & 2.91 & 1.21 \\
\hline
\end{tabular}

confidential information [AIK4] and knowledge [AIK5].

The analysis of variance was used to assess differences in information and knowledge dissemination across enterprise groups by the level of competence development. The analysed sample included data obtained in both groups (cluster organisations and technology parks) (Table 8).

The results of the analysis of variance showed that the dissemination of information and knowledge was rated the highest in the group of cooperating companies of similar development as compared to groups of companies of different level of development. However, the mean value for almost all variables was less than 3or slightly above, i.e. the value was consistent with the average rating. The differences of information and knowledge dissemination in various enterprise clusters were statistically significant for the variables of access to general and selective information, as well as for the variable of access to new knowledge. Access to a variety of general information and selective information and knowledge was significantly higher in groups of companies with a similar level of competence development.

\subsection{DisSEMINATION OF KNOWLEDGE}

Cooperating companies that have the same or similar competence in terms of the scope of the competence are more active in knowledge creation activities. Companies that collaborate with other cluster companies of similar expertise are statistically significantly more frequently involved in collaborative processes of new knowledge creation. $54.6 \%$ of the companies within the group that have reported cooperating with other cluster partners that have the same competence indicated their involvement in knowledge creation processes. In the group of companies that do not cooperate with other cluster companies of the same or similar competence, merely $19.3 \%$ reported their participation in knowledge creation activities together with other cluster companies. 
The collected data support the proposition that the dissemination of new knowledge within cluster firms depends on the proximity of an organisation's competence. Differences of participating in knowledge dissemination activity are related to differences in partnerships in terms of the competence scope proximity. Pearson's chi-square value is 35.47 , and the observed significance level is $\mathrm{p}<0.01$, which confirms the hypothesis that the engagement in knowledge creation activities depends on the competence proximity of cooperating firms in terms of the competence scope (Table 9).

The strength of the association was moderate between variables of companies participating in a partnership with the companies of proximal competence in terms of the scope of competence, and participating in knowledge dissemination together with other cluster companies (Cramer's $\mathrm{V}=0.364, \mathrm{p}<0.01$ ).

The collected data did not support the proposition that the dissemination of knowledge within cluster firms depended on the proximity of organisational competence in terms of the level of development (the level of development of technology, knowledge, and the quality of staff). $23.1 \%$ of the companies within the group that reported the cooperation primarily with other cluster partners having a lower level of development (in terms of technology, knowledge, quality of staff) indicated their involvement in knowledge creation processes. Cooperation in knowledge creation processes was noted by $37.5 \%$ and $35.6 \%$ of the respondents, respectively, representing companies that cooperate with other companies having a similar and higher level of development (a total of 35.4\% of all companies were involved in collaborative knowledge creation activities). Differences in the frequency of participation in knowledge creation activities among different groups of companies are not statistically significant (the significance of the chi-square test statistic was $p=0.367>0.05$ ). The behaviour of organisations in relation to cooperative activities for the development and dissemination of knowledge is independent of the differences between the cooperating organisations in terms of their level of competence development.

The crosstabs analysis of the research data showed that the differences in the frequency of participation in knowledge creation activities among the regional cluster and high technology (technology parks) enterprise groups were not statistically significant (the significance of the chi-square test statistic was $\mathrm{p}=0.607>0.05)$. The involvement of organisations in knowledge creation activities was reported by $33.6 \%$ of representatives of regional cluster companies and $30.7 \%$ of enterprises belonging to high-tech groups (technology parks). The second proposition that the dissemination of new knowledge within a group of cluster firms depends on specific features of the organizations, such as being an innovative high-tech industrial company, was not supported by our research.

A logistic regression analysis was performed to identify the impact of information dissemination among cluster companies and the effect made by the proximity of competence of cooperating organisations on the likelihood that cluster companies participated in knowledge creation activities. To evaluate the impact of different factors determining the involvement of organisations in knowledge creation and dissemination activities among the companies participating in the cluster, different models for the sample companies, cluster organisations and innovative parks companies were computed (Table 10).

Logistic regression models are statistically significant, $\mathrm{p}<0.01$. The first model of the total sample data explained (Nagelkerke R2) $37.50 \%$ of the variance in cluster companies' involvement in knowledge creation activities, while the result for the second model of the regional cluster sample scored $50.7 \%$, and the third model of high tech parks $-33.2 \%$, and, respectively, correctly classified $76.9 \%, 78.5 \%$, and $77.9 \%$ of cases in

Tab. 9. Results of the crosstabs analysis: [CPs] - [AIK6] ( $N=268)$

\begin{tabular}{|c|c|c|c|c|}
\hline AIK & & CPs1 (1-3) & CPs1 (4-5) & TOTAL \\
\hline \multirow{3}{*}{$\begin{array}{l}\text { AIK6: definitely not, } \\
\text { rather not, hard to say }\end{array}$} & Count & 138 & 44 & 182 \\
\hline & $\begin{array}{l}\% \text { within work with other companies that have/do not } \\
\text { have the same competence }\end{array}$ & $80.70 \%$ & $45.40 \%$ & $67.90 \%$ \\
\hline & $\%$ of total & $51.50 \%$ & $16.40 \%$ & $67.90 \%$ \\
\hline \multirow{3}{*}{$\begin{array}{l}\text { AIK6: rather yes, } \\
\text { definitely yes }\end{array}$} & Count & 33 & 53 & 86 \\
\hline & $\begin{array}{l}\% \text { within work with other companies that have/do not } \\
\text { have the same competence }\end{array}$ & $19.30 \%$ & $54.60 \%$ & $32.10 \%$ \\
\hline & $\%$ of total & $12.30 \%$ & $19.80 \%$ & $32.10 \%$ \\
\hline \multirow{2}{*}{ Total } & Count & 171 & 97 & 268 \\
\hline & $\%$ of total & $63.80 \%$ & $36.20 \%$ & $100.00 \%$ \\
\hline
\end{tabular}


Tab. 10. Parameters of the logistic regression models

\begin{tabular}{|c|c|c|c|c|c|c|c|c|c|}
\hline \multirow{2}{*}{ VARIABLES } & \multicolumn{3}{|c|}{ TOTAL SAMPLE, N=229 } & \multicolumn{3}{|c|}{$\begin{array}{l}\text { CLUSTER ORGANISATION SAMPLE, } \\
\qquad \mathrm{N}=93\end{array}$} & \multicolumn{3}{|c|}{ PARK SAMPLE, N=136 } \\
\hline & B & SIG. & $\operatorname{ExP}(B)$ & B & SIG. & $\operatorname{Exp}(B)$ & B & SIG. & $\operatorname{ExP}(B)$ \\
\hline AIK1 & 0.254 & 0.207 & 1.289 & 1.004 & 0.031 & 2.729 & 0.094 & 0.703 & 1.099 \\
\hline AIK2 & 0.203 & 0.378 & 1.225 & -0.484 & 0.226 & 0.616 & 0.515 & 0.103 & 1.674 \\
\hline AIK3 & 0.317 & 0.13 & 1.373 & 0.812 & 0.045 & 2.253 & 0.128 & 0.633 & 1.137 \\
\hline AIK4 & 0.612 & 0.001 & 1.844 & 0.905 & 0.026 & 2.473 & 0.534 & 0.015 & 1.705 \\
\hline CPI_1_2_3 & 0.026 & 0.932 & 1.026 & 0.615 & 0.307 & 1.849 & -0.11 & 0.777 & 0.895 \\
\hline CPs1_1_2_3 & 0.711 & 0.001 & 2.037 & 0.755 & 0.04 & 2.127 & 0.771 & 0.004 & 2.162 \\
\hline Constant & -6.466 & 0.000 & 0.002 & -11.107 & 0.000 & 0.000 & -5.825 & 0.000 & 0.003 \\
\hline \multicolumn{10}{|c|}{ Logistic regression results: } \\
\hline$\chi 2(6),(p)$ & \multicolumn{3}{|c|}{$73.028,(p<0.01)$} & \multicolumn{3}{|c|}{$43.95,(p<0.01)$} & \multicolumn{3}{|c|}{$36.524,(p<0.01)$} \\
\hline Nagelkerke $\mathrm{R}^{2}$ & \multicolumn{3}{|c|}{0.375} & \multicolumn{3}{|c|}{0.507} & \multicolumn{3}{|c|}{0.332} \\
\hline $\begin{array}{l}\text { Predicted percentage } \\
\text { correct }\end{array}$ & \multicolumn{3}{|r|}{76.9} & \multicolumn{3}{|r|}{78.5} & \multicolumn{3}{|r|}{77.9} \\
\hline
\end{tabular}

different samples. The variable of dissemination of confidential information between cluster partners (AIK4) and the variable of competence of collaborating firms (CPs1, 1 - different competence among the cluster partners, 2 - neither different nor similar competence among the cluster partners, and $3-$ similar competence among the cluster partners) added significantly to all three models, but the variable of access to selected information disseminated among cluster partners (AIK2) and the variable of competence of collaborating firms in terms of the level of development (CPI, 1 - partner's level of development is lower than the level of our company, 2 - partner's level of development is similar to the level of our company, and 3 - partner's level of development is higher than the level of our company) did not add significantly to either of the three.

For log regression parameter values, the likelihood that cluster firms would collaborate in knowledge production activities was calculated. For the data of the total sample, when the competence variable acquires values from 1 (cooperating firms have different competences) to 3 (collaborating firm competence is similar), and all variables of information dissemination gain the highest values (5), and the variable of the partner competence level gains the value of 2 (similar level of development), the likelihood that a firm would collaborate with cluster partners in the knowledge creation and dissemination processes increased from 0.773 to 0.934 . Similarly, when the variable of dissemination of confidential information between cluster partners acquired values from 1 (it is acknowledged that cooperating companies definitely do not share confidential information) to 5 (it is acknowledged that cooperating companies definitely share confidential information), and other variables of information dissemination and partner competence gain the highest values, the likelihood that firm would collaborate with cluster partners in the knowledge creation and dis- semination processes increased from 0.550 to 0.934 $(\operatorname{Prob}(\operatorname{AIK} 4(2))=0.693 ; \operatorname{Prob}(\operatorname{AIK} 4(3))=0.806 ; \quad \operatorname{Prob}$ $(\operatorname{AIK} 4(4))=0.885)$.

The results of the logistic regression model for the data of tech-parks show that the likelihood of access to knowledge dissemination processes in a group of clustered companies is associated with two statistically significant variables, namely, the availability of confidential information and competence of cooperating organisations. An increasing rating of access to confidential information and similar competence was associated with an increased likelihood of access to knowledge creation activities. For the data on the sample of tech-parks, when the competence variable acquired values from 1 (cooperating firms have different competences) to 3 (collaborating firm competence is similar), and all variables of information dissemination gained the highest values, and partner competence level variable gained the value of 2 (similar level of development), the likelihood that firm would collaborate with cluster partners in the knowledge creation and dissemination processes increased from 0.747 to 0.932. Similarly, when the variable of dissemination of confidential information between cluster partners acquired values from 1 to 5 , and other variables of the information dissemination and partner competence gained the highest values, the likelihood that firm would collaborate with cluster partners in the knowledge creation and dissemination processes increased from 0.619 to $0.932(\operatorname{Prob}(\operatorname{AIK} 4(2))=0.735$; Prob $(\operatorname{AIK} 4(3))=0.826 ; \operatorname{Prob}(\operatorname{AIK} 4(4))=0.890)$.

The results of the logistic regression model for the data of regional clusters show that variables of access to general information, access to information about the changes in the external environment, access to certain confidential information and the variable of competence of cooperating organisations added significantly to the model. Variables of access to general information and access to certain confidential information 
have the greatest influence on the variation of the dependent variable (respectively, $\operatorname{EXP}(B)=2.73$ and $\operatorname{EXP}(B)=2.47)$. A growing rating of access to general information is associated with an increased likelihood of access to knowledge creation activities in regional clusters. For the data of the sample for regional clusters, when the variable of access to general information acquired values from 1 to 5 , and all other variables of information dissemination gained the highest values, the competence level variable gained the value of 2 (a similar level of development), and the competence scope variable gained the value of 3 (similar competence), the likelihood that a firm would collaborate with cluster partners in the knowledge creation and dissemination processes increased from 0.391 to 0.973 $(\operatorname{Prob}(\operatorname{AIK} 1(2))=0.637 ; \operatorname{Prob}(\operatorname{AIK} 1(3))=0.827 ; \quad \operatorname{Prob}$ $(\operatorname{AIK1}(4))=0.929)$. Similarly, when the competence variable acquired values from 1 (cooperating firms have different competences) to 3 (collaborating firm competence is similar), and all variables of information dissemination gained the highest values, and the partner competence level variable gained the value of 2 (a similar level of development), the likelihood that a firm would collaborate with cluster partners in the knowledge creation and dissemination processes increased from 0.887 to 0.973 . The effect of competence proximity variable was almost the same in all three models.

Logistic regression models reflect the impact of information dissemination on the process of knowledge creation in clustered enterprise groups. A comparison of logistic regression models for regional cluster data and innovative technology park data suggests that information transfer processes and their impact on innovation and knowledge dissemination processes in regional clusters and technology parks differ significantly. Knowledge creation and dissemination processes in regional cluster companies are facilitated by the availability of different types of information, while the impact of general information and environmental information on knowledge creation processes is less significant in innovative park clusters. The collected data support the hypothesis that access to general and selected information about cluster partners is related to the dissemination of new knowledge within cluster companies.

\section{DISCUSSION OF THE RESULTS}

The paper analysed the impact of the proximity of competencies of cluster organisations on the dissemination of information and knowledge within the clus- ter. The comparison of the research results on competence proximity $[\mathrm{CP}]$ in cluster organisations and technology parks, leads to a conclusion that companies tend to participate in joint activities primarily with enterprises similar in terms of the level of competence development [CPl] (regardless of the degree of their diversity). Considering the scope of competences [CPs], cluster entities preferred cooperation with enterprises with the same (or very similar) [CPs1] or different (but complementary) set of competences [CPs2], while park entities similarly often decided to cooperate with each of the three distinguished groups of partners (that had the same/similar, a different/ complementary and completely different set of competences [CPs1]-[CPs3]).

Based on the conducted research, it can also be concluded that in cluster organisations and technology parks, better access to information and knowledge [AIK] was reported by partners with the same or very similar scope of competences [CPs1], as well as with different but complementary competences [CPs2]. It is important to note that this also included access to confidential information [AIK4] as well as to new knowledge [AIK5]. On the other hand, cooperation of companies with a too wide range of competences [CPs3] did not guarantee access to information, especially in science and technology parks. Moreover, there was a moderate relationship between the level of competence development $[\mathrm{CPl}]$ of enterprises representing both types of studied entities and access to information and knowledge resources [AIK] (except for access to confidential information and new knowledge in parks).

Furthermore, the research data showed that knowledge creation activities performed by cooperating cluster organisations depended on the proximity of the competencies of organisations, as well as on the nature of the information, disseminated within the cluster organisations. The capability-based theoretical perspective of organisational competence considers competence as a resource that enables various processes and capabilities of an organisation, such as the absorptive capacity - the capacity to acquire external information and exploit it for the activities of knowledge creation. Companies with proximal competence are likely to have a similar absorptive capacity, so the proximity of competence is related to more effective dissemination of information and knowledge among involved organisations. The results for the competence scope could be referenced to this state of knowledge. The results for organisational competence in terms of the proximity of the level of development were ambiguous. 
Based on the research, it can be concluded that access to general information about cluster organisations and relevant information about changes in the external environment, as well as sharing of certain confidential information with a cluster partner had a significant impact on the likelihood that cluster organisations would be able to integrate external information in organisation's knowledge creation activities. This result was in line with the theory of the absorptive capacity and a gradual process of information acquisition, transfer, assimilation, application and integration within an organisation's knowledge systems. Different results of information transfer that we obtained in the group of science and technology parks reflect the idea of the relative absorptive capacity. The relative absorptive capacity model states that the capability of an organisation to integrate knowledge depends on the compatibility of the knowledge transfer and development systems used by collaborating partners. Science and technology companies are characterised by more developed processes of learning, transfer and integration of knowledge, and creation of innovations. When companies of technology parks cooperate, the transfer and assimilation of information take place in coordinated compatible structures. Therefore, the impact of general and environmental information on knowledge creation in science and technology park companies is less important than in regional cluster companies.

\section{CONCLUSIONS}

The theoretical contribution is related to the results obtained by analysing the phenomenon of knowledge dissemination in business clusters, revealing the impact of the proximity of competencies of cooperating organisations and the nature of disseminated information. This study supports the notion derived from the theoretical underpinnings that the proximity of competencies is significant for the dissemination of information and the creation of new knowledge in groups of organisations. The findings were based on the concepts of organisational competence and the absorptive capacity and added to the state-of-the-art knowledge related to the phenomenon of industrial clusters.

These empirical findings also offer some practical implications for both cluster coordinators and park managers. The identified relationships between an organisation's competence and access to information and knowledge in cluster and park structures can be helpful in their design and development. Knowledge about the most desirable set of partner competences from the point of view of transferability of knowledge can be particularly useful in setting rules for entry into cluster organisations and technology parks (criteria for selecting cluster members and park tenants). It can also be valuable when creating smaller subgroups within these organisations (task or project groups) focused on achieving specific goals.

The study has some limitations. First, a relatively small sample, both from the point of view of the number of cluster organisations and technology parks (seven organisations in total) as well as the number of respondents (269 in total). Second, a small diversity in the sample, especially since it included only Polish organisations, which limits the possibility of generalising the conclusions. Nevertheless, the sample size was sufficient to perform the planned analyses, and the applied logic of sample selection (as a differentiating criterion: the sector in the case of cluster structures and the type of park in the case of park structures) allows a thesis to be put forward regarding a wider universality of the discovered regularities. This applies especially to countries with similar innovation and cluster policies. The third limitation is the subjectivity of conducted research (results were based on the subjective responses of respondents).

Future research should focus on developing the conceptual model, in which identified relationships between organisational competence and access to knowledge and information in cluster and park structures could be studied in greater detail. This model should consider additional factors that can act as a mediator or moderator in analysed relationships (e.g. involvement of companies in cluster or park activities, their technological capability and absorptive capacity, relationships with other cluster members or park tenants). It is also necessary to improve measurement tools by using an ordinal scale for all variables, as well as conducting exploratory and confirmatory factor analysis to test the measurement model. Furthermore, to test the conceptual model (preferably using structural equation modelling), the study should be conducted in a larger, more representative sample (considering national conditions, additional sectors of the economy, a different type of cluster organisations and parks etc.).

\section{LITERATURE}

Amit, R., \& Schoemaker, P. J. H. (1993). Strategic Assets and Organizational Rent. Strategic Management Journal, 14(1), 33-46. 
Boyatzis, R. E. (1982). The Competent Manager - A Model for Effective Performance. John Wiley \& Sons, Inc.

Camison, C., \& Forés, B. (2010). Knowledge absorptive capacity: New insights for its conceptualization and measurement. Journal of Business Research, 63, 707715. doi: 10.1016/j.jbusres.2009.04.022

Cohen, M. (1984). Conflict and Complexity: Goal Diversity and Organizational Search Effectiveness. American Political Science Review, 78(June), 435-454.

Cohen, W. M., \& Levinthal, D. A. (1990). Absorptive Capacity: A New Perspective on Learning and Innovation. Administrative Science Quarterly, 35, 128-152.

Danneels, E. (2016). Survey measures of first- and secondorder competences. Strategic Management Journal, 37(10), 2174-2188. doi: 10.1002/smj.2428

Dosi, G., \& Marengo, L. (2000). Some elements of an evolutionary theory of organizational competences. In $\mathrm{N}$. J. Foss (Ed.), The Theory of the Firm. Critical perspectives on business and management (pp. 50-73). London, United Kingdom: Routledge.

Eisenhardt, K. M., \& Martin, J. A. (2000). Dynamic capabilities: what are they? Strategic Management Journal, 21, 1105-1121.

Heéraud, J.-A. (2003) Regional Innovation Systems and European Research Policy: Convergence or Misunderstanding? European Planning Studies, 11(1), 41-56. doi: 10.1080/09654310303658

Kogut, B., \& Kulatilaka, N. (2001). Capabilities as Real Options. Organization Science, 12(6), 661-777. doi: 10.1287/orsc.12.6.744.10082

Lane, P. J., \& Lubatkin, M. (1998). Relative absorptive capacity and interorganizational learning. Strategic Management Journal, 19, 461-477.

Lindqvist, G., Ketels, C., \& Sölvell, Ö. (2013). The Cluster Initiative Greenbook. Stockholm, Sweden: Ivory Tower Publishers.

Lis, A. M. (2018). Współpraca w inicjatywach klastrowych. Rola bliskości w rozwoju powiązań kooperacyjnych [Cooperation in cluster initiatives: the role of proximity in the development of cooperative relationships]. Gdansk, Poland: Wydawnictwo Politechniki Gdanskiej.

Lis, A. M. (2019). The significance of proximity in cluster initiatives. Competitiveness Review: An International Business Journal, 29(3), 287-310. doi: 10.1108/CR08-2018-0050

Lis, A. M., \& Rozkwitalska, M. (2020). Technological capability dynamics through cluster organizations. Baltic Journal of Management, ahead-of-print. doi: 10.1108/BJM-02-2020-0046

Miranda, S., Orciuoli, F., Loia, V., \& Sampson, D. (2017). An ontology-based model for competence management. Data \& Knowledge Engineering, 107, 51-66. doi: 10.1016/j.datak.2016.12.001

Nelson, R. R., \& Winter, S. G. (2002). Evolutionary Theorizing in Economics. Journal of Economic Perspectives, 16(2), 23-46.

Niosi, J., \& Bas, T. G. (2001). The Competencies of Regions - Canada's Clusters in Biotechnology. Small Business Economics, 17, 31-42.

Østergaard, Ch. R., \& Park, E. (2015). What Makes Clusters Decline? A Study on Disruption and Evolution of a High-Tech Cluster in Denmark. Regional Studies, Taylor \& Francis Journals, 49(5), 834-849. doi: 10.1080/00343404.2015.1015975

Prahalad, C. K., \& Hamel, G. (1990). The Core Competence of the Corporation. Harvard Business Review, MayJune, 1-14.

Santos, F. M., \& Eisenhardt, K. M. (2005). Organizational boundaries and theories of organization. Organization Science, 16(5), 491-508. doi: 10.1287/ orsc. 1050.0152

Sölvell, Ö., Lindqvist, G., \& Ketels, C. (2003). The Cluster Initiative Greenbook. Stockholm, Sweden: Ivory Tower.

Štverková, H., \& Mynarzová, M. (2017). Cluster Initiatives in the Context of the BEE Model. Forum Scientiae Oeconomia, 5(3), 59-69. doi: 10.23762/FSO_vol5no3_17_4

Świadek, A. (2015). Horizontal spatial proximity and innovation activity in Polish regions. Polish Journal of Management Studies, 11(1), 147-157.

Tallman, S., Jenkins, M., Henry, N., \& Pinch, S. (2004). Knowledge, Clusters, and Competitive Advantage. Academy of Management Review, 29(2), 258-271.

Teece, D. J., Pisano, G., \& Shuen, A. (1997). Dynamic capabilities and strategic management. Strategic Management Journal, 18(7), 509-533.

Teece, D., \& Pisano, G. (1994). The Dynamic Capabilities of Firms: An Introduction. Working Paper, WP-94-103, IIASA International Institute for Applied Systems Analysis A-2361. Laxenburg, Austria.

Ter Wal, A. L. J., \& Boschma, R. A. (2011). Co-evolution of Firms, Industries and Networks in Space. Regional Studies, 45(7), 919-933. doi: 10.1080/00343400802662658

Wernerfelt, B. (1984). A Resource-Based View of the Firm. Strategic Management Journal, 5(2), 171-180.

Wernerfelt, B. (1995). The resource-based view of the firm: ten years after. Strategic Management Journal, 16, 171-174. doi: 10.1002/smj.4250160303

Winter, S. G. (2003). Understanding Dynamic Capabilities. Strategic Management Journal, 24, 991-995. doi: 10.1002/smj.318 